\title{
Glucose-6-phosphate dehydrogenase activity in somatic and germinal cells of the mouse testis
}

\author{
Janet T. Jones* and Sandra J. Andrews \\ Medical Research Council, Radiobiology Unit, Harwell, Didcot, Oxon. OX11 ORD, U.K.
}

\begin{abstract}
Summary. The activity of G6PD was examined by spectrophotometric and electrophoretic assays in cell fractions from the testes of mice at different ages (5-62 days). (1) The G6PD activity of the cells of the seminiferous tubule was as high or higher than that of the interstitial tissue. (2) The high G6PD activity of the testis of the immature mouse was mainly due to a high specific activity of the Sertoli cells which declined with age. (3) The G6PD activity was more easily lost during culture from the germinal cells than from the interstitial or Sertoli cells. (4) All the cell types of the testis contained G6PD and hexose-6-phosphate dehydrogenase. The functional significance of the high G6PD activity in the Sertoli cells of immature mice is not at present understood.
\end{abstract}

\section{Introduction}

Studies of testicular enzymes are important in two respects, firstly, for defining the functional characteristics of the different cell types present, and secondly, for studying the developmental changes which take place during germ cell maturation. Glucose-6-phosphate dehydrogenase (G6PD, EC 1.1.1.49) in the testes of rats and mice has been studied from both these points of view. Histochemical studies have indicated a high concentration of G6PD activity in the interstitial cells of the mouse, and have shown an increase in its activity following the depletion of germinal cells by Xirradiation (Ito, 1966). There is also an overall decrease in the level of G6PD activity in the mouse testis after 20 days of age, which has been attributed to a decrease in the proportion of interstitial and Sertoli cells (Shen \& Lee, 1976). On the other hand, assays of G6PD activity in cells separated from the testis have indicated that there is also enzyme activity present in the germinal cells of all stages from primary spermatocytes to spermatozoa (Erickson, 1976; Brock, 1977). There are two dehydrogenases in the mouse testis which will utilize glucose-6-phosphate as a substrate; G6PD, coded for by $G p d-2$ on the X chromosome, and hexose-6-phosphate dehydrogenase (H6PD, EC 1.1.1.47), coded for by $G p d-1$ on chromosome 4 (Brock, 1977).

The present studies were designed to examine the isoenzyme content and the levels of G6PD activity of both the somatic and germinal cells during the maturation of the testis.

\section{Materials and Methods}

Mice. The mice were $F_{1}$ hybrids from a $\mathrm{C} 3 \mathrm{H} / \mathrm{HeH} \times 101 / \mathrm{H}$ cross, except for the mice used to prepare samples for electrophoresis, which were of the parental strains. The animals were killed by cervical dislocation and the testes were removed aseptically. In studies with young mice, testes of two or more animals were pooled, but with animals over 20 days old two testes from a single mouse were used for each experiment.

Interstitial cells. The tunicae albugineae were removed and the interstitial cells were isolated from the seminiferous tubules by incubating the testes at $37^{\circ} \mathrm{C}$ in two changes, of 7 min each, of a solution of $0.1 \%$ trypsin (Difco, West Molesley, Surrey, U.K.) and 0.025\% EDTA in PBS (Dulbecco's phosphate-buffered saline, calcium and magnesium free; Oxoid, London, U.K.). Gentle pipetting was used to wash the cells from between the tubules, which suffered very little breakage during this process. The trypsin solution containing the interstitial cells was added to PBS con-

* Present address: Department of Biochemistry, University of Glasgow, Glasgow G12 8QQ, U.K. 
taining 5\% fetal calf serum (FCS; Gibco-Biocult Ltd, Hounslow, Middlesex, U.K.). The cells were then washed twice in PBS without FCS by centrifugation at $500 \mathrm{~g}$, resuspended in $1 \mathrm{ml} \mathrm{PBS}$ and sampled for protein determination and counting before further centrifugation and resuspension in the buffer to be used for the enzyme assay. The viability of these cell suspensions by trypan blue dye exclusion was $88 \pm 9.5 \%$ (mean \pm s.d.).

Germinal cells. After the trypsinizations, the seminiferous tubules were still intact but separated from each other. They were placed briefly in PBS with 5\% FCS, to stop the trypsin activity, and the mass of tubules was cut into fragments of 1-5 mm with scalpel blades. PBS was added to the resulting fragments, and they were gently aspirated with a Pasteur pipette. The fragments were allowed to settle, and the cells in the supernatant solution were removed and used as a fraction enriched in germinal cells. This method is similar to that used by Welsh \& Wiebe (1975) with rat testes. Because the Sertoli cells are tightly joined to one another, they remain as a network within the tubule wall fragments, while the later spermatocyte stages, spermatids and spermatozoa, which are closer to the lumen, are easily separated from the tubule wall fragments containing the Sertoli cells. The cells were washed twice in PBS, sampled for protein determination and counting, and suspended in the enzyme assay buffer. The viability was $92 \pm 9 \cdot 5 \%$ (mean \pm s.d.).

Sertoli cells. Sertoli cells were prepared from the remaining tubule fragments by the method of Tung, Dorrington \& Fritz (1975). The fragments were incubated at $33^{\circ} \mathrm{C}$ for $30-50 \mathrm{~min}$ in a collagenase medium (Dulbecco's Modified Eagle's Medium (Gibco) with $1 \mathrm{mg}$ collagenase (Sigma, Poole, Dorset, U.K.) $/ \mathrm{ml}$ ). The resulting smaller fragments were washed in PBS with $1 \%$ bovine serum albumin (BSA, Sigma), suspended in a serum-free medium (Dulbecco's MEM (Gibco) with 100 i.u. penicillin/ml, $100 \mu \mathrm{g}$ streptomycin/ml and $4 \mathrm{~mm}$-glutamine (all Flow Laboratories, Irvine, U.K.)) and cultured overnight at $33^{\circ} \mathrm{C}$. The Sertoli cells from the fragments attach to the culture dishes, while most of the germinal cells remain free in the medium (Steinberger \& Steinberger, 1966). After culture, the medium and unattached cells were removed, and the attached Sertoli cells harvested from the culture dishes with trypsin. Both the Sertoli cells and the unattached germinal cells were washed twice, sampled and suspended in the enzyme assay buffer. The viability of the Sertoli cells was $84 \pm 4 \cdot 5 \%$ (mean \pm s.d.).

Whole tubules. For determination of total tubule activity, intact seminiferous tubules were digested into a single cell suspension in the collagenase medium without further fractionation.

Assay of glucose-6-phosphate dehydrogenase. The assay method was that of Brinster (1966), except that the final dilution of cells and substrate in the cuvette, immediately before the assay, was made in a buffer containing Triton X-100, the final concentration being $0.07 \%$. The reaction was carried out in a volume of $0.7 \mathrm{ml}$ in a cuvette with $1-\mathrm{cm}$ light path, and the linear increase in absorbance at $340 \mathrm{~nm}$ was measured in a Pye Unicam SP 800 spectrophotometer. Protein was determined by the method of Lowry, Rosebrough, Farr \& Randall (1951) as modified by Hartree (1972).

Electrophoresis. Testis cell fractions were prepared from two strains of mice which vary at the $G p d-1$ locus. The 101 strain carries the $G p d-1^{a}$ allele, and has a slower moving, more active isoenzyme; the $\mathrm{C} 3 \mathrm{H}$ strain carries the $G p d-I^{\mathrm{b}}$ allele and has a faster moving, less active isoenzyme (Ruddle, Shows \& Roderick, 1968).

Tissues (kidney and testis) for electrophoresis were homogenized for $30 \mathrm{sec}$ in an Ultra-Turrax homogenizer (Janke \& Kunkel) at $20 \%$ (w/v) in Tris-HCl buffer $(50 \mathrm{~mm}, \mathrm{pH} 8.0)$ with $0.1 \%$ Triton $\mathrm{X}-100$. The homogenates were centrifuged for $30 \mathrm{~min}$ at $12500 \mathrm{~g}$ at $4^{\circ} \mathrm{C}$ and the supernatant was used for electrophoresis. Sperm extracts for electrophoresis were obtained by cutting up the vasa deferentia and the epididymides in PBS, aspirating the suspension, and then allowing the large debris to settle. The supernatant containing the spermatozoa was centrifuged, and the spermatozoa were resuspended in the Tris-HCl-Triton buffer and homogenized in the Ultra-Turrax homogenizer. The homogenate was centrifuged as above and the supernatant was used for electrophoresis. Cell suspensions from the testis were washed, centrifuged for $10 \mathrm{~min}$ at $500 \mathrm{~g}$, and the pellets resuspended in twice their volume of Tris-HCl-Triton buffer. The cell suspensions were kept for $1 \mathrm{~h}$ on ice with occasional shaking, centrifuged for $10 \mathrm{~min}$ at $500 \mathrm{~g}$ at $4^{\circ} \mathrm{C}$, and the supernatant was used for electrophoresis. NADP (nicotinamide adenine dinucleotide phosphate) at a final concentration of $0.7 \mathrm{mg} / \mathrm{ml}$ was added to extracts immediately before electrophoresis. 
Electrophoresis was carried out on cellulose acetate plates (Helena Laboratories, Texas, U.S.A.) for $25 \mathrm{~min}$ at $200 \mathrm{~V}$ with $0.2 \mathrm{M}$-Tris-glycine as the electrode buffer. The plate was stained by combining the following reagents in a warm agarose solution and pouring them over the plate: $0.096 \mathrm{M}-\mathrm{Tris}-\mathrm{HCl}$ buffer, pH 8.0; $0.009 \mathrm{M}-\mathrm{MgCl}_{2} ; 0.072 \mathrm{M}$-galactose-6-phosphate; 0.24 mg NADP/ml; $0.09 \mathrm{mg}$ phenazine methosulphate $/ \mathrm{ml} ; 0.36 \mathrm{mg}$ MTT (3-(4,5-dimethyl thiazolyl-2)-2,5-diphenyl tetrazolium bromide)/ml; 6.94 $\mathrm{mg}$ agarose/ml (E. Eicher, personal communication). Galactose-6-phosphate was used as the substrate because H6PD utilizes this substrate better than does G6PD (Ohno, Morrison \& Beutler, 1966; Beutler \& Morrison, 1967).

\section{Results}

\section{Experiment 1}

The specific activities of G6PD of cell suspensions from the interstitial cells and the cells of the whole seminiferous tubule of mice of various ages are given in Table 1. In mice up to 20 days of age, the activity within the tubule was greater than that of the interstitial cells, but decreased between 12 and 30 days. In mice of 30 days and older, the G6PD activities were similar.

Table 1. The specific activity of glucose-6-phosphate dehydrogenase ( $\mu \mathrm{mol}$ NADP reduced/min/mg protein) in interstitial and tubular (germinal and Sertoli) cells of the testes of mice at different ages

\begin{tabular}{|c|c|c|c|c|c|}
\hline \multirow[b]{2}{*}{ Fraction } & \multicolumn{5}{|c|}{ Age (days) } \\
\hline & 5 & 12 & 20 & 30 & 53 \\
\hline Interstitial cells & $0.015 \pm 0.013$ & $0.0104 \pm 0.013$ & $0.019 \pm 0.014$ & $0.038,0.052$ & $0.039,0.040$ \\
\hline Tubular cells & $0.094 \pm 0.033$ & $0.108 \pm 0.023$ & $0.055 \pm 0.018$ & $0.035,0.043$ & $0.027,0.041$ \\
\hline
\end{tabular}

Values are means \pm s.d. for 4 determinations.

\section{Experiment 2}

This experiment was designed to assess separately the contribution of the germinal cells and of the Sertoli cells to the enzyme activity of the tubule. The tubules of 14-62-day-old mice were separated into Sertoli cell- and germinal cell-enriched fractions for specific activity measurements (Table 2). The specific activity of G6PD in Sertoli cells was very high in young mice and declined to a level similar to that of the germinal cells as the testes matured. The activity of the germinal cell fraction declined between 10 and 30 days of age but the change was not as great as that in Sertoli cells. The activity of the interstitial cells was relatively high.

The results of Experiments 1 and 2 showed that the level of G6PD activity in the germinal cells of adult mice is as high as that in interstitial cells. In adult seminiferous tubules, the cell population is approximately $97.9 \%$ germinal cells and $2.1 \%$ Sertoli cells (Meistrich, Bruce \& Clermont, 1973). The specific activity of G6PD in the tubules of adult mice in our experiments was slightly lower than, but was of the same order as, the specific activities found by Erickson (1976) for separated spermatocytes and spermatids (0.05-0.08 $\mu \mathrm{mol}$ NADP reduced $/ \mathrm{min} / \mathrm{mg}$ protein).

\section{Experiment 3}

The specific activities of the various testicular fractions which were cultured are shown in Table 3. The unattached cells had a very low activity after culture, while the attached cells showed a relatively high activity.

When an unfractionated cell suspension from the whole tubules was cultured overnight and the activity of the attached and unattached cells was measured, the values obtained for the attached and unattached cells were $0.413 \pm 0.077$ and $0.027 \pm 0.011 \mu \mathrm{mol}$ NADP reduced $/ \mathrm{min} / \mathrm{viable}$ cell. The values were expressed in this way in case the protein from dead cells was affecting the values for specific activity of the unattached cells. 
Table 2. The specific activity of glucose-6-phosphate dehydrogenase ( $\mu \mathrm{mol}$ NADP reduced $/ \mathrm{min} / \mathrm{mg}$ protein) in cell fractions of the testes of mice at different ages

\begin{tabular}{lccc}
\hline \multirow{3}{*}{ Fraction } & \multicolumn{4}{c}{ Age (days) } \\
\cline { 2 - 4 } & 14 & 33 & 62 \\
\hline Interstitial cells & $0.046,0.062$ & $0.061,0.092$ & $0.030,0.043$ \\
Germinal cells & $0.112,0.125$ & $0.031,0.081$ & $0.030,0.063$ \\
Sertoli cells & $0.272,0.293$ & $0.036,0.050$ & $0.028,0.033$ \\
\hline
\end{tabular}

Table 3. The specific activity ( $\mu$ mol NADP reduced $/ \mathrm{min} / \mathrm{mg}$ protein) of G6PD in fractions of testis from 19-day-old mice before and after overnight culture

\begin{tabular}{llll}
\hline \multirow{2}{*}{ Fraction } & Before culture & Attached cells & Unattached cells \\
\cline { 3 - 4 } & & & \multicolumn{2}{c}{ After culture } \\
\hline $\begin{array}{l}\text { Interstitial cells } \\
\text { 'Germinal' fraction }\end{array}$ & $0.0304,0.0309$ & $0.0203,0.0329$ & \\
$\begin{array}{l}\text { Tubule wall } \\
\text { fragments }\end{array}$ & $0.0263,0.0303$ & $0.0337,0.0441$ & $0.0016,0.0028$ \\
\hline
\end{tabular}

These results indicate that, in the conditions of culture used, the G6PD activity is more easily lost from the germinal cells than from the somatic cells.

\section{Experiment 4}

Examination of the distribution of G6PD and H6PD showed that both enzymes were present in whole testis and in all other fractions except those of germinal cells cultured overnight, which showed neither enzyme (Plate 1). The enzyme activity of the cultured germinal cells was presumably too low to be detected on electrophoretic plates (see Table 3). In the preparations of interstitial cells and Sertoli cells, which were rather dilute, only the more active isoenzyme of H6PD can be seen on Plate 1. The activity of G6PD was much greater than that of H6PD in all fractions, even when galactose-6-phosphate was used as a substrate. When glucose-6-phosphate was used as a substrate, the G6PD band was so large and intense that it obscured the position of H6PD.

\section{Discussion}

During the maturation of the mouse testis there are changes in cellular composition which are paralleled by changes in G6PD activity. Bellve et al. (1977) have determined the proportion of Sertoli cells in prepubertal mice, and state that Sertoli cells comprise $84 \%$ of the testis at 6 days of age and that this proportion declines to $28 \%$ by 20 days. In mature mice, Sertoli cells comprise $2 \cdot 1 \%$ of the cells present (Meistrich et al., 1973) but there is, of course, a corresponding increase in both the number and proportion of the germinal cells of the tubule (Rugh, 1968). Our studies indicate that, during the development of the testis, there is a decrease in the G6PD specific activity of the Sertoli cells, and it seems, therefore, that the decrease in the G6PD activity of the whole testis noted by Shen \& Lee (1976) is due to the decrease in both the proportion and enzyme activity of the Sertoli cells.

The specific activity of the Sertoli cells seems to be inversely proportional to the number of germinal cells present. An indication that the decrease in the activity of the Sertoli cells might be reversed was reported by Kormano, Härkönen \& Kontinen (1964) who studied histochemically G6PD activity in rat testes after the animals had been made experimentally cryptorchid. In the 


\section{PLATE 1}

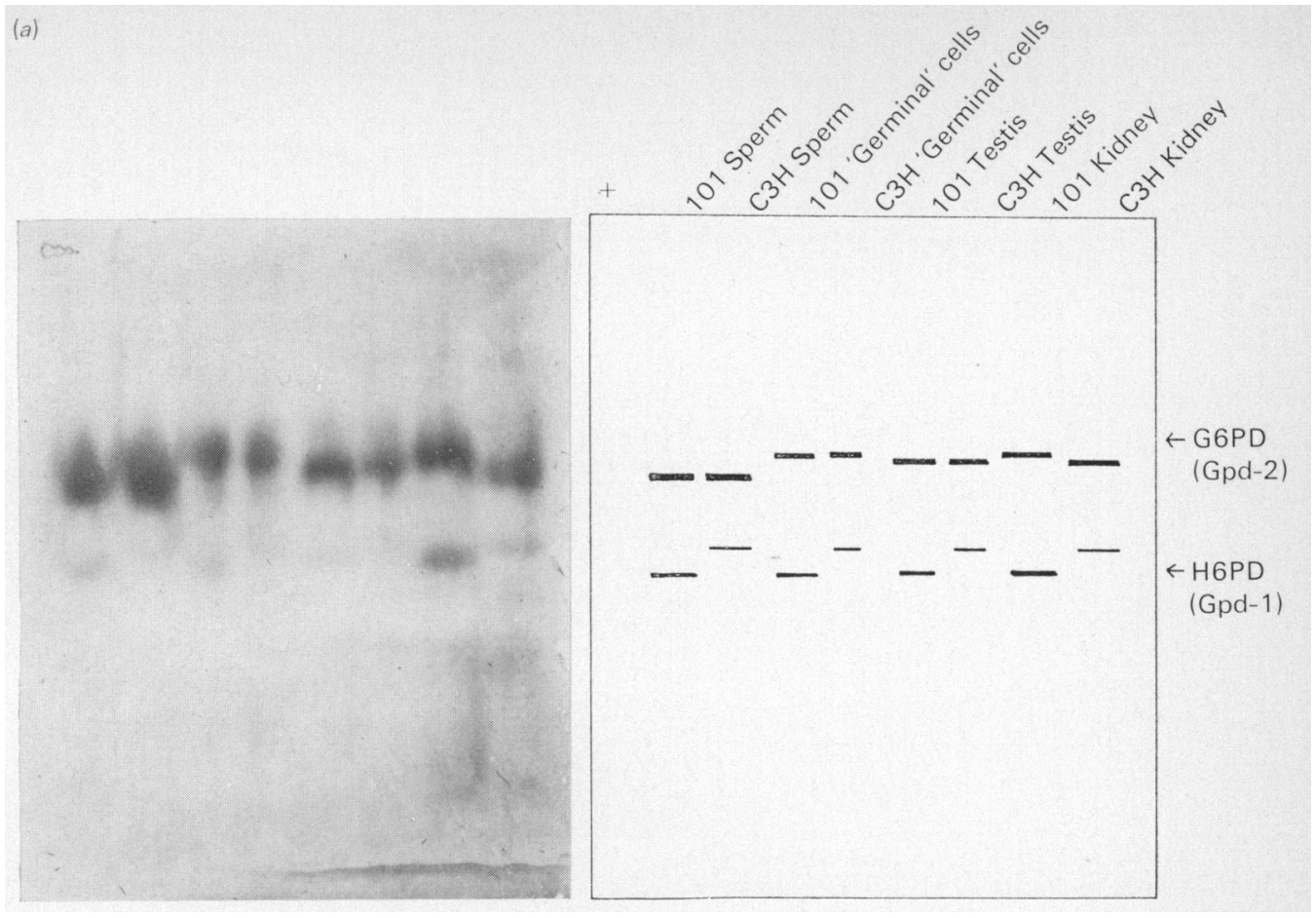

(b)

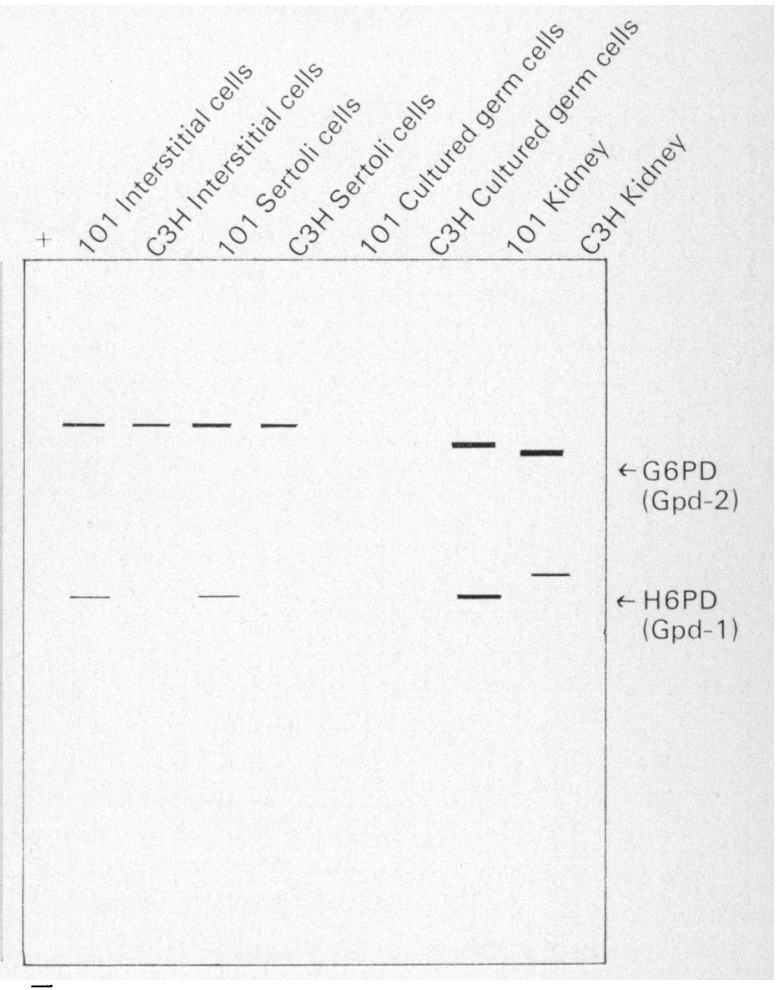

Cellulose acetate electrophoresis of extracts from cell suspensions and tissues (see text) of $\mathrm{C} 3 \mathrm{H}$ and 101 mice, stained with galactose-6-phosphate as substrate to show the activity of glucose-6-phosphate dehydrogenase (G6PD) and həxose-6-phosphate dehydrogenase (H6PD) 
normal rat testis, most of the enzyme activity appeared to be in the interstitial cells. When the rats were cryptorchid, and the germinal cells had disappeared from within the tubules, the stain for enzyme activity was more intense within the tubule than in the interstitium, perhaps indicating that the activity of the remaining Sertoli cells had increased. A similar effect can be seen in photographs of irradiated mouse testis tubules stained histochemically for G6PD activity (Ito, 1966): after depletion of the germinal cells, the staining at the periphery of the tubules is more apparent.

Our results which show G6PD activities in the tubule cells as high or higher than those in the interstitial cells are in contrast to the histochemical findings for most species, including the mouse (Blackshaw, 1970). In most histochemical studies, staining for G6PD activity is more intense in the interstitium than within the tubules, although in the photographs of sections published by lto (1966) of mouse and Vanha-Perttula, Bardin, Allison, Gumbreck \& Stanley (1970) of rat there is some evidence of enzyme activity near the periphery of the tubules which may be due to Sertoli cells. A possible explanation for the discrepancy between the results of the histochemical assay and the spectrophotometric assay may be that the enzyme within the germinal cells may be in a more labile form, and that the activity may be more easily lost from the germinal cells than from the interstitial cells and Sertoli cells during the sectioning and staining procedures used for the histochemical assay. When suspensions of tubule cells are cultured overnight, as in the present study, the somatic cells of the testis retained their G6PD activity, but the germinal cells, even though viable by trypan blue dye exclusion, lost most of their enzyme activity and this could be explained by the enzyme being more labile in the germinal cells and more stable in the somatic cells.

It has been suggested that the function of G6PD in the interstitial cells is to provide the NADPH which is required in the synthesis of hormonal steroids (Ito, 1966; Blackshaw, 1970; Blackshaw \& Elkington, 1970). Blackshaw \& Elkington (1970) observed an increase in the intensity of histochemical staining for G6PD in the testicular interstitium of rats between the ages of 10 and 30 days, and thereafter a slight decline, and they suggested that this change was due to an increased requirement for NADPH associated with the increase in hormone synthesis at that time. In our Exp. 1 there was an increase in enzyme activity of the interstitial cells during maturation, but in Exp. 2 the increase was only very slight. Further work is required to determine the developmental changes of this enzyme in the interstitial cells of the mouse, and also their functional significance.

The G6PD of the germinal cells has, in contrast, been said to be one of the "housekeeping" enzymes (Brock, 1977), presumably functioning as a glycolytic enzyme. It is not at present clear what function this enzyme has in Sertoli cells, or why the enzyme activity is so high in the Sertoli cells of immature mice.

We should like to thank Dr E. Eicher of The Jackson Laboratory for allowing access to details of her electrophoretic methods before publication.

\section{References}

Bellye, A.R., Cavicchia, J.C., Millette, C.F., O'Brien, D.A., Bhatnagar, Y.M. \& Dym, M. (1977) Spermatogenic cells of the prepuberal mouse. Isolation and morphological characterization. $J$. Cell Biol. 74, 68-85.

Beutler, E. \& Morrison, M. (1967) Localization and characteristics of hexose-6-phosphate dehydrogenase (glucose dehydrogenase). J. biol. Chem. 242, 52895293.

Blackshaw, A.W. (1970) Histochemical localization of testicular enzymes. In The Testis, Vol. II, pp. 73-123. Ed. A. D. Johnson, W. R. Gomes \& N. L. VanDemark. Academic Press, New York.

Blackshaw, A.W. \& Elkington, J.S.H. (1970) Developmental changes in lactate dehydrogenase isoenzymes in the testis of the immature rat. $J$. Reprod. Fert. 22, 69-75.
Brinster, R.L. (1966) Glucose-6-phosphate dehydrogenase activity in the preimplantation mouse embryo. Biochem.J. 101, 161-163.

Brock, W.A. (1977) Evidence against gene expression after meiosis in the male mouse. J. exp. Zool. 202, 68-80.

ERICKSON, R.P. (1976) Glucose-6-phosphate dehydrogenase activity changes during spermatogenesis: possible relevance to $\mathrm{X}$-chromosome inactivation. Devl Biol. 53, 134-137.

Hartree, E.F. (1972) Determination of protein: a modification of the Lowry method that gives a linear photometric response. Analyt. Biochem. 48, 422-427.

Iro, M. (1966) Histochemical observations of oxidative enzymes in irradiated testis and epididymus. Radiat. Res. 28, 266-277.

Downloaded from Bioscientifica.com at 04/26/2023 05:30:54AM 
Kormano, M., HÄRKönen, M. \& Kontinen, E. (1964) Effect of experimental cryptorchidism on the histochemically demonstrable dehydrogenases of the rat testis. Endocrinology 74, 44-51.

LOWRY, O.H., ROSEbrough, N.J., FARR, A.L. \& RANDALl, R.J. (1951) Protein measurement with the Folin-phenol reagent. J. biol. Chem. 193, 265-275.

Meistrich, M.L., BruCe, W.R. \& Clermont, Y. (1973) Cellular composition of fractions of mouse testis cells following velocity sedimentation separation. Expl Cell Res. 79, 213-227.

Ohno, S., Morrison, M. \& Beutler, E. (1966) Hexose6-phosphate dehydrogenase found in human liver. Science, N.Y.153, 1015-1016.

RUddle, F.H., Shows, T.B. \& ROderICK, T.H. (1968) Autosomal control of an electrophoretic variant of G6PD in the mouse. Genetics, Princeton 58, 599-606.

RuGH, R. (1968) The Mouse, its Reproduction and Development. Burgess Publishing Co., Minneapolis.
SHEN, R.-S. \& LEe, I.P. (1976) Developmental patterns of enzymes in mouse testis. J. Reprod. Fert. 48, 301-305.

Steinberger, A. \& Steinderger, E. (1966) In vitro culture of rat testicular cells. Expl Cell Res. 44, 443-452.

Tung, P.S., Dorrington, J.H. \& FrITz, I.B. (1975) Structural changes induced by follicle stimulating hormone or dibutyryl cyclic AMP on presumptive Sertoli cells in culture. Proc. natn. Acad. Sci. U.S.A. 72, 1838-1842.

Vanha-Pertrula, T., Bardin, C.W., Allison, J.E., Gumbreck, L.G. \& Stanley, A.J. (1970) Testicular feminization in the rat: morphology of the testis. Endocrinology 87, 611-619.

WeLsh, M.J. \& Wiebe (1975) Rat Sertoli cells: a rapid method for obtaining viable cells. Endocrinology 96,618-624.

Received 28 March 1978 